\title{
Pattern formation in models of plankton dynamics. A synthesis
}

\author{
Horst MALCHOW ${ }^{\mathrm{a} *}$, Sergei PETROVSKII ${ }^{\mathrm{b}}$, Alexander MEDVINSKY ${ }^{\mathrm{c}}$ \\ a Institute of Environmental Systems Research, Department of Mathematics \& Computer Science, University of \\ Osnabrück, 49069 Osnabrück, Germany \\ b Shirshov Institute for Oceanology, Russian Academy of Sciences, Nakhimovsky Prosp. 36, Moscow 117218, \\ Russia \\ ${ }^{c}$ Institute for Theoretical and Experimental Biophysics, Russian Academy of Sciences, Pushchino, Moscow \\ Region 142290, Russia
}

\begin{abstract}
The history of modelling plankton dynamics is already quite long and has been initiated by fishery science in the early 20th century. The main aim of modelling population dynamics is to improve the understanding of the functioning of food chains and webs and their dependence on internal and external conditions. Hence, mathematical models of biological population dynamics have not only to account for growth and interactions but also for spatial processes like random or directed and joint or relative motion of species as well as the variability of the environment. Early attempts began with physicochemical diffusion, exponential growth and Lotka-Volterra type interactions. These approaches have been continuously refined to more realistic descriptions of the development of natural populations. The aim of this paper is to give an extensive introduction to the subject and the bibliography. The fascinating variety of spatio-temporal patterns in such systems and the governing mechanisms of their generation and further dynamics are described and related to plankton. (C) 2001 Ifremer/CNRS/IRD/Éditions scientifiques et médicales Elsevier SAS
\end{abstract}

Résumé - Mode de formation des modèles de dynamique planctonique. Une synthèse. L'histoire de la modélisation de la dynamique du plancton est déjà plutôt longue puisqu'elle a débuté au début du $20^{\mathrm{e}}$ siècle avec les études sur les pêches. L'axe de cette modélisation est d'améliorer la compréhension du fonctionnement du réseau trophique et de ses relations avec les facteurs externes et internes. Aussi, les modèles mathématiques de dynamique des populations doivent non seulement tenir compte des déplacements des espèces au hasard ou dirigés, relatifs ou combinés ainsi que de la variabilité de l'environnement. Les premiers essais débutèrent avec la diffusion physico-chimique, la croissance exponentielle et les interactions de type Lotka-Volterra. Ces approches ont été régulièrement affinées vers des descriptions plus réalistes du développement des populations naturelles. L'objectif de cet article est d'introduire ce sujet et la bibliographie afférente. La variété infinie des schémas spatio-temporels dans de tels systèmes et les mécanismes directeurs de leur naissance ainsi que les futures dynamiques sont décrits et reliés au plancton. (C) 2001 Ifremer/CNRS/IRD/Éditions scientifiques et médicales Elsevier SAS

modelling / pattern formation / plankton patchiness / self-organization

modélisation / schémas de formation / agrégation du plancton / auto-organisation

*Correspondence and reprints: fax: +495419692599.

E-mail address: malchow@uos.de (H. Malchow). 


\section{INTRODUCTION}

The exploration of pattern formation mechanisms in non-linear complex systems is one of the central problems of natural, social, and technological sciences. The development of the theory of self-organized temporal, spatial or functional structuring of non-linear systems far from equilibrium has been one of the milestones of structure research Haken, 1977; Nicolis and Prigogine 1977). The occurrence of multiple steady states and transitions from one to another after critical fluctuations, the phenomena of excitability, oscillations, waves and, in general, the emergence of macroscopic order from microscopic interactions in various non-linear nonequilibrium systems in nature and society has required and stimulated many theoretical and, if possible, experimental studies. Mathematical modelling has turned out to be one of the useful methods to improve the understanding of such structure generating mechanisms.

\section{PLANKTON AND MODELS OF PLANKTON DYNAMICS: OVERVIEW}

In the 17th century, the Dutch pioneer microscopist Anton van Leeuwenhoek was probably the first human being to see minute creatures, which he called animalcules, in pond water (Hallegraeff, 1988). The German Victor Hensen who organized Germany's first big oceanographic expedition in 1889 (Hensen, 1892; Porep, 1970) introduced the term plankton (from the Greek planktos meaning made to wander).

Phytoplankton are microscopic plants that drive all marine ecological communities and the life within them. Due to their photosynthetic growth, the world's phytoplankton generate half of the oxygen that mankind needs for maintaining life and it absorbs half of the carbon dioxide that may be contributing to global warming. It is not only oxygen and carbon dioxide but also other substances and gases that are recycled by phytoplankton, e.g. phosphorus, nitrogen and sulphur compounds Bain, 1968: Ritschard, 1992; Duinker and Wefer 1994: Malin. 1997). Hence, phytoplankton are one of the main factors controlling the further development of the world's climate and there is a vast literature supporting that (cf. Charlson et al. 1987. Williamson and Gribbin 1991).
Zooplankton are the animals in plankton. In marine zooplankton, both herbivores and predators occur; herbivores graze on phytoplankton and are eaten by zooplankton predators. Together, phyto- and zooplankton form the basis for all food chains and webs in the sea. In its turn, the abundance of the plankton species is affected by a number of environmental factors such as water temperature, salinity, sunlight intensity, biogen availability etc. (Raymont. 1980: Sommer. 1994). Temporal variability of the species composition is caused by seasonal changes and trophical prey-predator interactions between phyto- and zooplankton. The latter have first been introduced by Lotka_1925 and Volterra (1926).

Because of its apparent importance, the dynamics of plankton systems have been under continuous investigation during more than a hundred years. It should be noted that, practically from the very beginning, regular plankton studies have combined field observations, laboratory experiments and mathematical modelling. It was in the 19th century that fisheries stimulated the interest in plankton dynamics because strong positive correlations between zooplankton and fish abundance were found. The already mentioned German plankton expedition of 1889 was mainly motivated by fisheries interests. At the same time, fishery science began to develop. In the beginning of the 20th century, the first mathematical models were developed in order to understand and to predict fish stock dynamics and its correlations with biological and physical factors and human interventions (cf. Cushing. 1975: Gulland.1977: Steele, 1977)

The contemporary mathematical modelling of phytoplankton productivity has its roots in the work of Fleming (1939), Ivlev (1945), Riley (1946), Odum (1956) and others. A review of the developments has been given by Droop (1983). Recently, a collection of the most frequently used models has been published Behrenfeldt and Falkowski, 1997).

The control of phytoplankton blooming by zooplankton grazing has been modelled first by Fleming Eleming. 1939) using a single ordinary differential equation for the temporal dynamics of phytoplankton biomass. Other approaches have been the construction of data-fitted functions Riley, 1946, 1963) and the application of standard Lotka-Volterra equations to describe the preypredator relation of phytoplankton and zooplankton $\mathrm{Se}-$ gel and Jackson, 1972; Dubois, 1975; Levin and Segel, 
1976: Vinogradov and Menshutkin. 1977: Mimura and Murray. 1978) More realistic descriptions of zooplankton grazing with functional responses to phytoplankton abundance have been introduced by [vlev (1945) with a certain modification by Mayzaud and Poulet (1978) Holling-type response terms Holling_ 1959) which are also known from Monod or Michaelis-Menten saturation models of enzyme kinetics (Michaelis and Menten. 1913. Monod and Jacob. 1961) are just as much in use (cf. Steele and Henderson. 1981. 1992a. 1992b: Scheffer 1991a. 1998: Malchow, 1993; Truscott and Brindley, 1994a.1994b.

Observed temporal patterns are the well-known stable prey-predator oscillations as well as the oscillatory or monotonous relaxation to one of the possible multiple steady states. Excitable systems are of special interest because their long-lasting relaxation to the steady state after a supercritical external perturbation like a sudden temperature increase or nutrient inflow is very suitable to model red or brown tides Beltrami, 1989, 1996; Truscott and Brindley, 1994a_1994b).

Regarding the temporal variability of plankton species abundance, the limits of its predictability are of particular interest. At early stages, the development of mathematical models of marine ecosystems was driven by the idea that the more species were explicitly included into the model the higher would be its predictive ability. As a result, a number of many-species models appeared allowing for a detailed structure of the food web of the community (cf. DeAngelis, 1992; Iørgensen, 1994; Yodzis, 1994). However, the real predictive ability of this class of models is not very high and rarely exceeds a few weeks. Moreover, an increasing number of model agents may sometimes even worsen the properties of the model. This apparent paradox can be explained in terms of dynamical chaos (May, 1974). It should be noted that, although the strict evidence of chaotic behaviour of natural populations is still absent, stronger and stronger indications in favour of its existence are appearing (Scheffer, 1991h, 1998; Costantino et al. 1995. 1997; Dennis et al. 1995; Godfray and Hassell, 1997: Huisman and Weissing, 1999) Chaotic population dynamics essentially changes the approach to the system predictability (cf. Scheffer, 1991b), and makes conceptual few-species models of as much use as many-species ones. Moreover, few-species models can sometimes be even more instructive since they take into account only the principal features of the community functioning (cf. Pascual, 1993; Petrovskii and Malchow
1999.2001. Another interesting problem is the dynamics of externally forced systems. This ideally periodic forcing appears rather naturally due to daily, seasonal or annual cycles of photosynthetically active radiation, temperature, nutrient availability, etc. (Evans and Parslow. 1985. Fruscott, 1995; Popova et al, 1997; Ryahchenko et al. 19977. Natural forcings are of course subject to a certain environmental noise. A number of forced models for parts or for the complete food chain (from nutrients, phytoplankton and zooplankton to planktivorous fish) have been investigated and many different routes to chaotic dynamics have been demonstrated Kuznetsov et al. 1992: Ascioti et al. 1993: Doveriet al. 1993: Rinaldiand Muratori, 1993. Rinaldi et al 1993. Steffen and Malchow. 1996a. 1996b: Scheffer et al. 1997: Steffen et al. 1997.

The abundance of plankton species is not only subject to temporal changes but also depends on space. The distinct spatial heterogeneity of plankton distribution (patchiness) is found in many field observations SSteele. 1974. 1978. Easham, 1978: Mackas and Boyd, 1979; Greene et al. 1992; Abhott, 1993) This phenomenon takes place on all scales, from centimetres to thousands of kilometres. A number of explanations has been suggested, particularly, relating the spatial structure of a plankton system to marine turbulence (Platt, 1972) or to the unhomogeneity of the temperature field in the ocean (Denman, 1976) A well-studied stripy plankton pattern is due to the trapping of populations of sinking microorganisms in Langmuir circulation cells (Stommel, 1948; Leihovich, 1993). Other physically determined plankton distributions such as steep density gradients due to local temperature differences, nutrient upwelling, turbulent mixing or internal waves have also been reported Yoder et al. 1994: Eranks, 1997; Abraham, 1998)

On a small spatial scale of some tens of centimetres and under relative physical uniformity, differences in the 'diffusive' mobility of individuals and the ability of locomotion might create finer spatial structures, e.g. due to bioconvection and gyrotaxis (Platt. 1961: Winet and Iahn. 1972: Pedley and Kessler. 1992: Timm and Okubo 1994). Until now for certain bacteria but not for plankton, the mechanism of diffusion-limited aggregation Witten and Sander. 1981) has been proposed and experimentally proven for the spatial fingering of colonies Matsushita and Fujikawa, 1990; Ben-Jacob et al., 1992) 
Thus, mathematical models of plankton population dynamics have not only to account for growth and interactions but also for spatial processes like random or directed and joint or relative motion of species as well as the variability of the environment. According to a widely accepted point of view, it is the interplay of phytoplankton and zooplankton growth, interactions and transport that yields the whole variety of spatio-temporal population structures, in particular the phenomenon of plankton patchiness (cf. Easham, 1978: Okwho, 1980). The mathematical modelling requires the use of reaction-diffusion and perhaps advection equations. A good introduction to the latter field has been provided by Holmes et al_(1994)

Since the classic paper by Turing (1952) on the role of non-equilibrium reaction-diffusion patterns in biomorphogenesis, dissipative mechanisms of spontaneous spatial and spatio-temporal pattern formation in a homogeneous environment are of continuous interest in theoretical biology and ecology. Turing showed that the non-linear interaction of at least two agents with considerably different diffusion coefficients can give rise to spatial structure. Segel and Jackson (1972) were the first to apply Turing's idea to a problem in population dynamics: the dissipative instability in the prey-predator interaction of phytoplankton and herbivorous copepods with higher herbivore motility. Levin and Segel (1976) suggested this scenario of spatial pattern formation for a possible origin of planktonic patchiness. Recently, local bistability, predator-prey limit-cycle oscillations, plankton front propagation and the generation and drift of planktonic Turing patches were found in a minimal phytoplankton-zooplankton interaction model Malchow 1993.1994 that was originally formulated by Scheffer (1991a) accounting for the effects of nutrients and planktivorous fish on alternative local equilibria of the plankton community.

Kierstead and Slohodkin (1953) and Skellam (1951) were perhaps the first to think of the critical size problem for plankton patches, presenting their nowadays called Kiss model with the coupling of exponential growth and diffusion of a single population. Of course, their patches are unstable because this coupling leads to an explosive spatial spread of the initial patch of species with surprisingly the same diffusive front speed as the asymptotic speed of a logistically growing population Luther. 1906. Eisher, 1937; Kolmogorov et al., 1937).
Populations with an Allee effect CAllee. 1931:Allee et al. 1949) i.e. when the existence of a minimum viable number of species of a population yields two stable population states - extinction and survival - at its carrying capacity, show a spatial critical size as well (Schlögl. 1972. Nitzan et al. 1974: Eheling and SchimanskyGeier 1980. Malchow and Schimansky-Geier, 1985. Lewis and Kareiva, 1993; Petrovskii, 1994) Population patches greater than the critical size will survive, the others will go extinct. However, bistability and the emergence of a critical spatial size do not necessarily require an Allee effect, and logistically growing preys with a parametrized predator of type II or III functional response can also exhibit two stable steady states and the related hysteresis loops (cf. Ludwig et al., 1978; Wissel, 1989).

The consideration of dynamic predation leads to the full spectrum of spatial and spatio-temporal patterns such as regular and irregular oscillations, propagating fronts, target patterns and spiral waves, pulses as well as stationary spatial patterns. Many of these structures were first known from oscillating chemical reactions (cf. Field and Burger, 1985), but have never been observed in natural plankton populations. However, spirals have been seen in the ocean as rotary motions of plankton patches on a kilometre scale (Wyatt,1973) Furthermore, they have been found to be important in parasitoid-host systems (Boerlijst et_al, 1993) For other motile microorganisms, travelling waves such as targets or spirals have been found in the cellular slime mold Dictyostelium discoideum Gerisch 1968, 1971; Keller and Segel, 1970: Segel and Stoeckly 1972: Segel 1977: Newell 1983: Alt and Hoffmann, 1990: Siegert and Weiier, 1991: Steinhock et al, 1991; Ivanitsky et al, 1994; Vasiev ett al. 1994:_Höfer et al. 1995). These amoebae are chemotactic species, i.e. they move actively up the gradient of a chemical attractant and aggregate. Chemotaxis is a kind of density-dependent cross-diffusion Keller and Segel,1971a, 1971b) and it is an interesting open question whether there is preytaxis in plankton or not. However, there is some evidence of chemotaxis in certain phytoplankton species Ikegami et al. 1995). Bacteria like Escherichia coli or Bacillus subtilis also show a number of complex colony growth patterns Shapiro and Hsu, 1989; Shapiro and Trubatch, 1991) different to the already mentioned diffusion-limited aggregation patterns. Their emergence requires cooperativity as well as active motion of the species which 
has also been modelled as density-dependent diffusion and predation (Kawasaki et al. 1995a. 1995b).

An important point is that the spatial dimensions of the plankton community functioning also provide new routes to chaotic dynamics. The emergence of diffusion-induced spatio-temporal chaos has been found along a linear nutrient gradient (Pascmal, 1993). Chaotic oscillations behind propagating diffusive fronts are found in a preypredator model (Sherratt et al, 1995, 1997); a similar phenomenon is observed in a mathematically similar model of a chemical reactor (Merkin et al, 1996; David son, 1998)

Recently it has been shown that the appearance of chaotic spatio-temporal oscillations in a prey-predator system is a somewhat more general phenomenon and must not be attributed to front propagation or to an unhomogeneity of environmental parameters (Petrovskii and Malchow 1999.2001. Conditions for the emergence of threedimensional spatial and spatio-temporal patterns after differential-flow-induced instabilities (Rovinsky and Menzinger. 1992) of spatially uniform populations were derived (Malchow. 1995. 1996.1998) and illustrated by patterns in Scheffer's model (Scheffer. 1991a). Instabilities of the spatially uniform distribution can appear if phytoplankton and zooplankton move with different velocities regardless of which one is faster. This mechanism of generating patchy patterns is more general than the Turing mechanism which depends on strong conditions on the diffusion coefficients; thus, one can expect a wide range of its application in population dynamics.

Thus, the dynamics of the plankton communities, particularly processes of pattern formation, have been under intensive investigation during the past few decades. As a result, considerable progress in understanding principal features of plankton system functioning has been achieved. Still, many mechanisms of the spatio-temporal variability of natural plankton populations are not known yet. Pronounced physical patterns like thermoclines, upwelling, fronts and eddies often set the frame for the biological processes. However, under conditions of relative physical uniformity, the temporal and spatiotemporal variability can be a consequence of the coupled non-linear biological and chemical dynamics Levin and Segel. 1976: Steele and Henderson, 1992a). Sommer 1994.1996) has emphasized the importance of biological dynamics during phytoplankton blooms. Daly and Smith (1993) concluded ".... that biological processes may be more important at smaller scales where behaviour such as vertical migration and predation may control the plankton production, whereas physical processes may be more important at larger scales in structuring biological communities ...". Q'Brien and Wroblewski (1973) introduced a dimensionless parameter, containing the characteristic water speed and the maximum specific biological growth rate, to distinguish parameter regions of biological and physical dominance (cf. also Wroblewski_et al. 1975: Wroblewski and O'Brien. 1976.

Physical and biological processes may differ significantly not only at spatial but also at temporal scales. Particularly, the effect of external hydrodynamical forcing on the appearance and stability of non-equilibrium spatiotemporal patterns has been studied (Malchow and Shigesada.1994) making use of the separation of the different time scales of biological and physical processes. A channel under tidal forcing served as a hydrodynamical model system with a relatively high matter detention time. Examples were provided at different time scales: the simple physical transport and deformation of a spatially non-uniform initial plankton distribution as well as the biologically determined formation of a localized spatial maximum of phytoplankton biomass. Plankton pattern formation is essentially dependent on the interference of various physical (light, temperature, hydrodynamics) and biological factors (nutrient supply, predation) (cf. Platt. 1972: Denman, 1976: Easham, 1978) In nature, it has been observed that the direction of motion of plankton patches does not always coincide with the direction of the water flow (Wyatt, 1971, 1973) and as the spatial scale becomes greater than approximately $100 \mathrm{~m}$, phytoplankton behaves successively less like a simple passive quantity distributed by turbulence Nakata and Ishikawa 1975: Powell et al. 1975: Powell and Okwhe, 1994. Similarly, the spatial variability of zooplankton abundance differs essentially from the environmental variability at scales less than a few dozens kilometres Weher et al. 1986). This indicates that biological factors play an essential role in the emergence of plankton patchiness Steele and Henderson. 1981.

\section{REFERENCES}

Abbott, M., 1993. Phytoplankton patchiness: ecological implications and observation methods. In: Levin, S.A., Powell, T.M., Steele, J.H. (Eds.), Patch Dynamics. Lecture Notes in Biomathematics, vol. 96. Springer-Verlag, Berlin, pp. 37-49. 
Abraham, E.R., 1998. The generation of plankton patchiness by turbulent stirring. Nature 391, 577-580.

Allee, W.C., 1931. Animal Aggregations: A Study in General Sociology. University of Chicago Press, Chicago.

Allee, W.C., Emerson, A.E., Park, O., Park, T., Schmidt, K.P., 1949. Principles of Animal Ecology. Saunders, Philadelphia.

Alt, W., Hoffmann, G., 1990. Biological Motion, Lecture Notes in Biomathematics, vol. 89. Springer-Verlag, Berlin.

Ascioti, F.A., Beltrami, E., Carroll, T.O., Wirick, C., 1993. Is there chaos in plankton dynamics? J. Plankton Res. 15, 603-617.

Bain, R.C. Jr, 1968. Predicting DO variations caused by algae. Journal of the Sanitary Engineering Division, Proceedings of the American Society of Civil Engineers, pp. 867-881.

Behrenfeldt, M.J., Falkowski, P.G., 1997. A consumer's guide to phytoplankton primary productivity models. Limnol. Oceanogr. 42, 1479-1491.

Beltrami, E., 1989. A mathematical model of the brown tide. Estuaries $12,13-17$.

Beltrami, E., 1996. Unusual algal blooms as excitable systems: The case of "brown-tides". Environ. Model. Assess. 1, 19-24.

Ben-Jacob, E., Shmueli, H., Shochet, O., Tenenbaum, A., 1992. Adaptive self-organization during growth of bacterial colonies. Physica A87, 378-424.

Boerlijst, M.C., Lamers, M.E., Hogeweg, P., 1993. Evolutionary consequences of spiral waves in a host parasitoid system. Proc. R. Soc. Lond. B253, 15-18.

Charlson, R.J., Lovelock, J.E., Andreae, M.O., Warren, S.G., 1987. Oceanic phytoplankton, atmospheric sulphur, cloud albedo and climate. Nature 326, 655-661.

Costantino, R.F., Cushing, J.M., Dennis, B., Desharnais, R.A., 1995. Experimentally induced transitions in the dynamic behaviour of insect populations. Nature 375, 227-230.

Costantino, R.F., Desharnais, R.A., Cushing, J.M., Dennis, B., 1997. Chaotic dynamics in an insect population. Science 275, 389-391.

Cushing, D.H., 1975. Marine Ecology and Fisheries. Cambridge University Press, Cambridge.

Daly, K.L., Smith, W.O., 1993. Physical-biological interactions influencing marine plankton production. Annu. Rev. Ecol. Syst. 24, 555-585.

Davidson, F.A., 1998. Chaotic wakes and other wave-induced behavior in a system of reaction-diffusion equations. Int. J. Bifurcation Chaos 8, 1303-1313.

DeAngelis, D.L., 1992. Dynamics of Nutrient Cycling and Food Webs. Chapman and Hall, London.

Denman, K.L., 1976. Covariability of chlorophyll and temperature in the sea. Deep-Sea Res. 23, 539-550.

Dennis, B., Desharnais, R.A., Cushing, J.M., Costantino, R.F., 1995. Nonlinear demographic dynamics: Mathematical models, statistical methods, and biological experiments. Ecol. Monogr. 65, 261-281.

Doveri, F., Scheffer, M., Rinaldi, S., Muratori, S., Kuznetsov, Yu. A., 1993. Seasonality and chaos in a plankton-fish model. Theor. Pop. Biol. 43, 159-183.
Droop, M.R., 1983. 25 years of algal growth kinetics. Bot. Mar. XXVI, 99-112.

Dubois, D., 1975. A model of patchiness for prey-predator plankton populations. Ecol. Model. 1, 67-80.

Duinker, J., Wefer, G., 1994. Das $\mathrm{CO}_{2}$-Problem und die Rolle des Ozeans. Naturwissenschaften 81, 237-242.

Ebeling, W., Schimansky-Geier, L., 1980. Nonequilibrium phase transitions and nucleation in reacting systems, Proceedings of the 6th International Conference on Thermodynamics, Merseburg, pp. $95-100$.

Evans, G.T., Parslow, S., 1985. A model of annual plankton cycles. Biol. Oceanogr. 3, 327-347.

Fasham, M.J.R., 1978. The statistical and mathematical analysis of plankton patchiness. Oceanogr. Mar. Biol. Ann. Rev. 16, 43-79.

Field, R.J., Burger, M. (Eds.), 1985. Oscillations and Travelling Waves in Chemical Systems. Wiley, New York.

Fisher, R.A., 1937. The wave of advance of advantageous genes. Ann. Eugen. 7, 355-369.

Fleming, R.H., 1939. The control of diatom populations by grazing. J. Cons. Perm. Int. Explor. Mer 14, 210-227.

Franks, P.J.S., 1997. Spatial patterns in dense algal blooms. Limnol. Oceanogr. 42, 1297-1305.

Gerisch, G., 1968. Cell aggregation and differentiation in Dictyostelium. In: Moscona, A.A., Monroy, A. (Eds.), Current Topics in Developmental Biology, vol. 3. Academic Press, New York, pp. 157-197.

Gerisch, G., 1971. Periodische Signale steuern die Musterbildung in Zellverbänden. Naturwissenschaften 58, 430-438.

Godfray, C., Hassell, M., 1997. Chaotic beetles. Science 275, 323-326.

Greene, C.H., Widder, E.A., Youngbluth, M.J., Tamse, A., Johnson, G.E., 1992. The migration behavior, fine structure, and bioluminescent activity of krill sound-scattering layer. Limnol. Oceanogr. 37, 650-658.

Gulland, J.A., 1977. Fish Population Dynamics. Wiley, London.

Haken, H., 1977. Synergetics. An Introduction. Springer Series in Synergetics, vol. 1. Springer-Verlag, Berlin.

Hallegraeff, G.M., 1988. Plankton. A Microscopic World. E.J. Brill, Leiden.

Hensen V. (Ed.), 1892. Ergebnisse der in dem Atlantischen Ocean von Mitte Juli bis bis Anfang November 1889 ausgeführten PlanktonExpedition der Humboldt-Stiftung. Kiel und Leipzig.

Höfer, T., Sherratt, J.A., Maini, P.K., 1995. Cellular pattern formation during Dictyostelium aggregation. Physica D85, 425-444.

Holling, C.S., 1959. Some characteristics of simple types of predation and parasitism. Can. Entomol. 91, 385-398.

Holmes, E.E., Lewis, M.A., Banks, J.E., Veit, R.R., 1994. Partial differential equations in ecology: Spatial interactions and population dynamics. Ecology 75, 17-29.

Huisman, J., Weissing, F.J., 1999. Biodiversity of plankton by species oscillations and chaos. Nature 402, 407-410. 
Ikegami, S., Imai, I., Kato, J., Ohtake, H., 1995. Chemotaxis toward inorganic phosphate in the red tide alga Chattonella antiqua. J. Plankton Res. 17, 1587-1591.

Ivanitsky, G.R., Medvinsky, A.B., Tsyganov, M.A., 1994. From the dynamics of population autowaves generated by living cells to neuroinformatics. Physics - Uspekhi 37, 961-989.

Ivlev, V.S., 1945. Biologicheskaya produktivnost' vodoemov. Usp. Sovrem. Biol. XIX, 98-120.

Jørgensen, S.E., 1994. Fundamentals of Ecological Modelling. Elsevier, Amsterdam.

Kawasaki, K., Mochizuki, A., Shigesada, N., 1995a. A mathematical model of pattern formation in a bacterial colony. Control Measurement 34, 811-816 (in Japanese).

Kawasaki, K., Mochizuki, A., Matsushita, M., Umeda, T., Shigesada, N., 1995b. Modeling spatio-temporal patterns generated by Bacillus subtilis. J. Theor. Biol. 188, 177-185.

Keller, E.F., Segel, L.A., 1970. Initiation of slime mold aggregation viewed as an instability. J. Theor. Biol. 26, 399-415.

Keller, E.F., Segel, L.A., 1971a. Model for chemotaxis. J. Theor. Biol. 30, 225-234.

Keller, E.F., Segel, L.A., 1971b. Travelling bands of chemotactic bacteria: A theoretical analysis. J. Theor. Biol. 30, 235-248.

Kierstead, H., Slobodkin, L.B., 1953. The size of water masses containing plankton blooms. J. Mar. Res. XII, 141-147.

Kolmogorov, A., Petrovskii, I., Piskunov, N., 1937. Étude de l'équation de la diffusion avec croissance de la quantité de matière et son application à un problème biologique. Bull. Univ. Moscou Sér. Int. Section A1, 1-25.

Kuznetsov, Yu. A., Muratori, S., Rinaldi, S., 1992. Bifurcations and chaos in a periodic predator-prey model. Int. J. Bifurcation Chaos 2, $117-128$.

Leibovich, S., 1993. Spatial aggregation arising from convective processes. In: Levin, S.A., Powell, T.M., Steele, J.H. (Eds.), Patch Dynamics. Lecture Notes in Biomathematics, vol. 96. SpringerVerlag, Berlin, pp. 110-124.

Levin, S.A., Segel, L.A., 1976. Hypothesis for origin of planktonic patchiness. Nature 259, 659.

Lewis, M.A., Kareiva, P., 1993. Allee dynamics and the spread of invading organisms. Theor. Popul. Biol. 43, 141-158.

Lotka, A.J., 1925. Elements of Physical Biology. Williams \& Wilkins, Baltimore.

Ludwig, D., Jones, D.D., Holling, C.S., 1978. Qualitative analysis of insect outbreak systems: the spruce budworm and forest. J. Anim. Ecol. 47, 315-332.

Luther, R., 1906. Räumliche Ausbreitung chemischer Reaktionen. Z. Elektrochem. 12, 596-600.

Mackas, D.L., Boyd, C.M., 1979. Spectral analysis of zooplankton spatial heterogeneity. Science 204, 62-64.

Malchow, H., 1993. Spatio-temporal pattern formation in nonlinear nonequilibrium plankton dynamics. Proc. R. Soc. Lond. B251, 103-109.

Malchow, H., 1994. Nonequilibrium structures in plankton dynamics. Ecol. Model. 75/76, 123-134.
Malchow, H., 1995. Flow- and locomotion-induced pattern formation in nonlinear population dynamics. Ecol. Model. 82, 257-264.

Malchow, H., 1996. Nonlinear plankton dynamics and pattern formation in an ecohydrodynamic model system. J. Mar. Syst. 7, 193-202.

Malchow, H., 1998. Flux-induced instabilities in ionic and populationdynamical interaction systems. Z. Phys. Chem. 204, 35-107.

Malchow, H., Schimansky-Geier, L., 1985. Noise and Diffusion in Bistable Nonequilibrium Systems. Teubner-Texte zur Physik, vol. 5. Teubner-Verlag, Leipzig.

Malchow, H., Shigesada, N., 1994. Nonequilibrium plankton community structures in an ecohydrodynamic model system. Nonlinear Processes Geophys. 1, 3-11.

Malin, G., 1997. Sulphur, climate and the microbial maze. Nature 387, 857-859.

Matsushita, M., Fujikawa, H., 1990. Diffusion-limited growth in bacterial colony formation. Physica A168, 498-506.

May, R., 1974. Biological populations with nonoverlapping generations: stable ponts, stable cycles and chaos. Science 186, 645-667.

Mayzaud, P., Poulet, S.A., 1978. The importance of the time factor in the response of zooplankton to varying concentrations of naturally occurring particulate matter. Limnol. Oceanogr. 23, 1144-1154.

Merkin, J.H., Petrov, V., Scott, S.K., Showalter, K., 1996. Waveinduced chemical chaos. Phys. Rev. Lett. 76, 546-549.

Michaelis, L., Menten, M., 1913. Die Kinetik der Invertinwirkung. Biochem. Z. 49, 333-369.

Mimura, M., Murray, J.D., 1978. On a diffusive prey-predator model which exhibits patchiness. J. Theor. Biol. 75, 249-262.

Monod, J., Jacob, F., 1961. General conclusions: Teleonomic mechanisms in cellular metabolism, growth and differentiation. Cold Spring Harbor Symp. Quant. Biol. 26, 389-401.

Nakata, K., Ishikawa, R., 1975. Fluctuation of local phytoplankton abundance in coastal waters. Jpn. J. Ecol. 25, 201-205.

Newell, P.C., 1983. Attraction and adhesion in the slime mold Dictyostelium. In: Smith, J.E. (Ed.), Fungal Differentiation. A Contemporary Synthesis. Mycology Series, vol. 43. Marcel Dekker, New York, pp. 43-71.

Nicolis, G., Prigogine, I., 1977. Self-organization in Nonequilibrium Systems. Wiley, New York.

Nitzan, A., Ortoleva, P., Ross, J., 1974. Nucleation in systems with multiple stationary states. Faraday Symp. Chem. Soc. 9, 241-253.

O'Brien, J.J., Wroblewski, J.S., 1973. On advection in phytoplankton models. J. Theor. Biol. 38, 197-202.

Odum, H.T., 1956. Primary production in flowing waters. Limnol. Oceanogr. 1, 102-117.

Okubo, A., 1980. Diffusion and Ecological Problems: Mathematical Models. Biomathematics, vol. 10. Springer-Verlag, Berlin.

Pascual, M., 1993. Diffusion-induced chaos in a spatial predator-prey system. Proc. R. Soc. Lond. B251, 1-7.

Pedley, T.J., Kessler, J.O., 1992. Hydrodynamic phenomena in suspensions of swimming microorganisms. Annu. Rev. Fluid Mech. 24, $313-358$. 
Petrovskii, S.V., 1994. Approximate determination of the magnitude of the critical size in the problem of the evolution of an ecological impact. J. Eng. Phys. Thermophys. 66, 346-352.

Petrovskii, S.V., Malchow, H., 1999. A minimal model of pattern formation in a prey-predator system. Math. Comp. Model. 29, 49-63.

Petrovskii, S.V., Malchow, H., 2001. Wave of chaos: new mechanism of pattern formation in spatiotemporal population dynamics. Theor. Pop. Biol. 59, 157-174.

Platt, J.R., 1961. Bioconvection patterns in cultures of free-swimming organisms. Science 133, 1766-1767.

Platt, T., 1972. Local phytoplankton abundance and turbulence. DeepSea Res. 19, 183-187.

Popova, E.E., Fasham, M.J.R., Osipov, A.V., Ryabchenko, V.A., 1997. Chaotic behaviour of an ocean ecosystem model under seasonal forcing. J. Plankton Res. 19, 1495-1515.

Porep, R., 1970. Der Physiologe und Planktonforscher Victor Hensen (1835-1924), Sein Leben und Werk. Kieler Beiträge zur Geschichte der Medizin und Pharmazie, No. 9. Karl Wachholtz Verlag, Neumünster.

Powell, T.M., Okubo, A., 1994. Turbulence, diffusion and patchiness in the sea. Proc. R. Soc. Lond. B343, 11-18.

Powell, T.M., Richerson, P.J., Dillon, T.M., Agee, B.A., Dozier, B.J., Godden, D.A., Myrup, L.O., 1975. Spatial scales of current speed and phytoplankton biomass fluctuations in Lake Tahoe. Science 189, 1088-1090.

Raymont, J.E.G., 1980. Plankton and Productivity in the Oceans. Pergamon Press, Oxford.

Riley, G.A., 1946. Factors controlling phytoplankton populations on Georges Bank. J. Mar. Res. 6, 54-73.

Riley, G.A., 1963. Theory of food-chain relations in the ocean. In: Hill, M.N. (Ed.), The Sea, vol. 2. Wiley, New York, pp. 438-463.

Rinaldi, S., Muratori, S., 1993. Conditioned chaos in seasonally perturbed predator-prey models. Ecol. Model. 69, 79-97.

Rinaldi, S., Muratori, S., Kuznetsov, Yu. A., 1993. Multiple attractors, catastrophes and chaos in seasonally perturbed predator-prey communities. Bull. Math. Biol. 55, 15-35.

Ritschard, R.L., 1992. Marine algae as a $\mathrm{CO}_{2}$ sink. Water Air Soil Pollut. 64, 289-303.

Rovinsky, A.B., Menzinger, M., 1992. Chemical instability induced by a differential flow. Phys. Rev. Lett. 69, 1193-1196.

Ryabchenko, V.A., Fasham, M.J.R., Kagan, B.A., Popova, E.E., 1997. What causes short term oscillations in ecosystem models of the ocean mixed layer? J. Mar. Syst. 13, 33-50.

Scheffer, M., 1991a. Fish and nutrients interplay determines algal biomass: a minimal model. Oikos 62, 271-282.

Scheffer, M., 1991b. Should we expect strange attractors behind plankton dynamics - and if so, should we bother? J. Plankton Res. 13, 1291-1305.

Scheffer, M., 1998. Ecology of Shallow Lakes. Population and Community Biology Series, vol. 22. Chapman and Hall, London.

Scheffer, M., Rinaldi, S., Kuznetsov, Yu.A., van Nes, E.H., 1997. Seasonal dynamics of Daphnia and algae explained as a periodically forced predator-prey system. Oikos 80, 519-532.
Schlögl, F., 1972. Chemical reaction models for nonequilibrium phase transitions. Z. Phys. 253, 147-161.

Segel, L.A., 1977. A theoretical study of receptor mechanisms in bacterial chemotaxis. SIAM J. Appl. Math. 32, 653-665.

Segel, L.A., Jackson, J.L., 1972. Dissipative structure: an explanation and an ecological example. J. Theor. Biol. 37, 545-559.

Segel, L.A., Stoeckly, B., 1972. Instability of a layer of chemotactic cells, attractant and degrading enzyme. J. Theor. Biol. 37, 561-585.

Shapiro, J.A., Hsu, C., 1989. Escherichia coli K-12 cell-cell interactions seen by time-lapse video. J. Bacteriol. 171, 5963-5974.

Shapiro, J.A., Trubatch, D., 1991. Sequential events in bacterial colony morphogenesis. Physica D49, 214-223.

Sherratt, J.A., Lewis, M.A., Fowler, A.C., 1995. Ecological chaos in the wake of invasion. Proc. Natl. Acad. Sci. USA 92, 2524-2528.

Sherratt, J.A., Eagan, B.T., Lewis, M.A., 1997. Oscillations and chaos behind predator-prey invasion: mathematical artifact or ecological reality? Phil. Trans. R. Soc. Lond. B352, 21-38.

Siegert, F., Weijer, C.J., 1991. Analysis of optical density wave propagation and cell movement in the cellular slime mold Dictyostelium discoideum. Physica D49, 224-232.

Skellam, J.G., 1951. Random dispersal in theoretical populations. Biometrika 38, 196-218.

Sommer, U., 1994. Planktologie. Springer-Verlag, Berlin.

Sommer, U., 1996. Algen, Quallen, Wasserfloh, Die Welt des Planktons. Springer-Verlag, Berlin.

Steele, J.H., 1974. The Structure of Marine Ecosystems. Harvard University Press, Cambridge MA.

Steele, J.H., 1977. Fisheries Mathematics. Academic Press, London.

Steele, J.H., 1978. Spatial Pattern in Plankton Communities, NATO Conference Series: IV, Marine Sciences, vol. 3. Plenum Press, New York.

Steele, J.H., Henderson, E.W., 1981. A simple plankton model. Am. Nat. 117, 676-691.

Steele, J.H., Henderson, E.W., 1992a. The role of predation in plankton models. J. Plankton Res. 14, 157-172.

Steele, J.H., Henderson, E.W., 1992b. A simple model for plankton patchiness. J. Plankton Res. 14, 1397-1403.

Steffen, E., Malchow, H., 1996a. Chaotic behaviour of a model plankton community in a heterogeneous environment. In: Schweitzer, F. (Ed.), Self-organisation of Complex Structures: From Individual to Collective Dynamics. Gordon and Breach, London, pp. 331-340.

Steffen, E., Malchow, H., 1996b. Multiple equilibria, periodicity, and quasiperiodicity in a model plankton community. Senckenberg. Marit. 27, 137-143.

Steffen, E., Malchow, H., Medvinsky, A.B., 1997. Effects of seasonal perturbations on a model plankton community. Environ. Model. Assess. 2, 43-48.

Steinbock, O., Hashimoto, H., Müller, S.C., 1991. Quantitative analysis of periodic chemotaxis in aggregation patterns of Dictyostelium discoideum. Physica D49, 233-239.

Stommel, H., 1948. Trajectories of small bodies sinking slowly through convection cells. J. Mar. Res. 8, 24-29. 
Timm, U., Okubo, A., 1994. Gyrotaxis: A plume model for selffocusing micro-organisms. Bull. Math. Biol. 56, 187-206.

Truscott, J.E., 1995. Environmental forcing of simple plankton models. J. Plankton Res. 17, 2207-2232.

Truscott, J.E., Brindley, J., 1994a. Ocean plankton populations as excitable media. Bull. Math. Biol. 56, 981-998.

Truscott, J.E., Brindley, J., 1994b. Equilibria, stability and excitability in a general class of plankton population models. Phil. Trans. R. Soc. Lond. A347, 703-718.

Turing, A.M., 1952. On the chemical basis of morphogenesis. Phil. Trans. R. Soc. Lond. B237, 37-72.

Vasiev, B.N., Hogeweg, P., Panfilov, A.V., 1994. Simulation of Dictyostelium discoideum aggregation via reaction-diffusion model. Phys. Rev. Lett. 73, 3173-3176.

Vinogradov, M.E., Menshutkin, V.V., 1977. The modelling of open-sea ecosystems. In: Goldberg, E.D. (Ed.), The Sea: Ideas and Observations on Progress in the Study of the Seas, vol. 6. Wiley, Berlin, pp. 891-921.

Volterra, V., 1926. Variazioni e fluttuazioni del numero d'individui in specie animali conviventi. Mem. Acad. Lineei III 6, 31-113.

Weber, L.H., El-Sayed, S.Z., Hampton, I., 1986. The variance spectra of phytoplankton, krill and water temperature in the Antarctic ocean south of Africa. Deep-Sea Res. 33, 1327-1343.
Williamson, P., Gribbin, J., 1991. How plankton change the climate. New Scientist 16 March, 48-52.

Winet, H., Jahn, T., 1972. On the origin of bioconvection fluid instabilities in Tetrahymena culture systems. Biorheology 9, 87-104.

Wissel, C., 1989. Theoretische Ökologie. Springer-Verlag, Berlin.

Witten, T.A., Sander, L.M., 1981. Diffusion-limited aggregation, a kinetic critical phenomenon. Phys. Rev. Lett. 47, 1400-1403.

Wroblewski, J.S., O'Brien, J.J., 1976. A spatial model of phytoplankton patchiness. Mar. Biol. 35, 161-175.

Wroblewski, J.S., O’Brien, J.J., Platt, T., 1975. On the physical and biological scales of phytoplankton patchiness in the ocean. Mém. Soc. R. Sci. Liège VII, 43-57.

Wyatt, T., 1971. Production dynamics of Oikopleura dioica in the Southern North Sea, and the role of fish larvae which prey on them. Thalassia Jugosl. 7, 435-444.

Wyatt, T., 1973. The biology of Oikopleura dioica and Fritillaria borealis in the Southern Bight. Mar. Biol. 22, 137-158.

Yoder, J.A., Ackleson, S.G., Barber, R.T., Flament, P., Balch, W.M., 1994. A line in the sea. Nature 371, 689-692.

Yodzis, P., 1994. The trophodynamics of whole ecological communities. In: Levin, S. (Ed.), Frontiers in Mathematical Biology. Lecture Notes in Biomathematics, vol. 100. Springer-Verlag, Berlin, pp. 443-453. 